\title{
Harry Potter and the Diagnostic and Statistical Manual: Muggle Disorders in the Wizarding World
}

J.K. Rowling's Harry Potter series is a literary phenomenon unlike any other, bringing record-breaking sales, blockbuster movies, theme parks and a worldwide fan base that remains strong nearly a decade after the publication of the last book. It has also become a popular topic for academic study, inspiring books, (e.g. Granger, 2008a, 2008b; Kern, 2003) scholarly conferences, (e.g. Granger, 2012; Harry Potter Conference, n.d.) and doctoral dissertations (e.g. Hippard, 2007; Moses, 2014). Rowling is well known for the meticulous planning and research she did when writing the series. The fruits of her efforts turn up at all levels, from the largest overarching themes to the smallest of apparently throwaway details. For instance, in a 2007 interview, she noted:

To invent this wizard world, I've learned a ridiculous amount about alchemy. Perhaps much of it I'll never use in the books, but I have to know in detail what magic can and cannot do in order to set the parameters and establish the stories' internal logic. (Simpson, 1998).

Not only are historical alchemical elements such as the Philosopher's Stone (regretfully changed to "Sorcerer's Stone" for U.S. audiences) and Nicholas Flamel used in the first book, literary alchemy permeates the entire series (See Granger, 2008a; 2008b for review).

Even a single reference to a Dursley family houseplant can be loaded with meaning. The Agapanthus in their garden that Dumbledore offhandedly compliments as "flourishing" in Harry Potter and the Half-Blood Prince (HBP, Rowling, 2005, p. 55) is a flower commonly called "African Lily," but not a true member of the lily family 
(Chase, Reveal \& Fay, 2009), much as Aunt Petunia is a poor substitute for Harry's mother Lily. Rowling is clearly a writer who makes few arbitrary choices in her fiction.

There is evidence throughout the series that Rowling extended her research into the field of abnormal psychology, drawing on both her own encounters with mental illness and current professional diagnostic criteria. Though the wizarding world is largely ignorant of the science of psychology, Rowling's creations provide vivid and detailed images of at least four recognizable psychiatric disorders. Rowling herself has confirmed that two elements were explicitly inspired by her own life: dementors from her own bout of clinical depression (Amini, 2008; Runcie, 2007; Treneman, 2000) and the amnesic state of Frank and Alice Longbottom from a friend's mother with Alzheimer's disease (Anelli \& Spartz, 2005). Two other characters can be seen as caricatures of traumainduced disorders: Mad-Eye Moody as post-traumatic stress disorder (PTSD) and Winky the house-elf as Stockholm syndrome.

The Diagnostic and Statistical Manual of Mental Disorders (DSM) is the standard professional handbook listing criteria for the diagnosis of mental illness. First published by the American Psychiatric Association in 1952, it has undergone five major revisions; the current edition, the $D S M-V$, was published in 2013. Rowling describes her creations in rich details, often matching specific symptoms listed in the $D S M-I V$ (the edition that was current when she wrote the series) and other psychology resources.

\section{Harry Potter and the Behavioral Sciences}

Psychologists began to notice the Harry Potter series as soon as it was clear it would be a cultural phenomenon. The first peer-reviewed psychology journal article on the series (Noel-Smith, 2001) was published shortly after Harry Potter and the Goblet of 
Fire (GoF). Since then, much of the psychological scholarship about Harry Potter has fallen into one of three categories: 1) empirical studies on the effects of reading the series (e.g. Hsu, Jacobs, Altmann, \& Conrad, 2015; Vezzali, Stathi, Giovannini, Capozza, \& Trifiletti, 2014) 2) descriptive research on the factors behind the series' unprecedented popularity (e.g. Brown \& Patterson, 2010) and 3) literary analysis, usually from a Jungian or Freudian perspective (e.g. Noel-Smith, 2001; Rosegrant, 2009).

The series' popularity has also made Harry Potter a useful therapeutic and teaching tool in a variety of settings, from discussion with teens on the dangers of alcohol use (Welsh, 2007) to helping patients cope with trauma (Merkell \& Merkell, 2008; Strimell, 2004) to promoting self-acceptance in gifted adolescents (Frank \& McBee, 2003) to improving the effectiveness of clinicians and counselors (Conn, 2002; Gibson, 2007). Before the series was even concluded, two therapists had published books or articles describing how they incorporate Harry Potter-related activities into therapy with children (Mulholland, 2006; Noctor, 2006); another book (Merkell \& Merkell, 2008) came after the series was concluded. Even psychologists who do not explicitly study Harry Potter find references to the well-known characters useful in communicating their findings. Stine-Morrow (2007) calls the capacity of personal choice to affect age-related cognitive decline "the Dumbledore hypothesis," while Nelissen and Zeelenberg (2009) named the guilt-induced tendency to self-punish "the Dobby effect."

As might be expected from children's books, scholars from a variety of disciplines have found developmental psychology theories to be useful lenses through which to view the series. Young adult literature scholar Seymor (2012) relates the increasing moral ambiguity that unfolds in the series to Piaget's model of moral 
development. English professors Whited and Grimes offer a similar treatment to Kohlberg's model of moral development, arguing for Harry's progression to stage five, the highest accessible to children. The historian Kern (2003) finds support from both Kohlberg and Kohlberg's critics Grinder and Gilligan for his thesis that the series offers a Stoic philosophy of moral decision-making. Psychologists Binnendyk and SchonertReichl (2002) also interpret the series through Kohlberg's model, arguing that the first five stages correspond to the characters of Dobby, Draco, Ron, Hermione and Harry. Other scholars look to the series as an illustration of psychologically healthy parenting practices. Seden (2002) argues that reading the series promotes empathy in child welfare professionals, as they compare the good and bad examples of the Weasleys and the Dursleys as surrogate parents for Harry. Winters (2011) sees the series as an argument against overprotective parenting, again with Dudley Dursley as a negative example. Finally, for a completely different developmental angle, Mills (2006) uses Kristiva's theory of the abject to interpret the imagery of toilets and bathrooms in the series.

The lack of wizard psychology. While Muggle psychologists have eagerly boarded the Hogwarts Express and employed the tools of their trade to illuminate Harry's world, the interest is not reciprocated. Mental health issues are all but invisible in the wizarding community (Murakami, 2006). As seen in Harry Potter and the Order of the Phoenix (OotP), the study of the human brain is restricted to a room the Department of Mysteries. Understanding thought processes is apparently considered as daunting an undertaking as the study of time, space, love and death, with any research findings restricted to the Unspeakables. 
Other than school nurse Madame Pomfrey occasionally administering a Calming Draught to an overly stressed student, no psychological services exist at Hogwarts School (Murakami, 2006). While witches and wizards seem to have their own set of physical ailments (e.g. spattergroit) and trained professional Healers in place to treat them, mental illnesses are largely undefined, except with the generic term "madness." (Murakami, 2006). Wizards recognize that symptoms like hearing voices, delusional thinking or memory gaps are abnormal, hence Ginny and Harry's fear that they are "going mad" in Harry Potter and the Chamber of Secrets (CoS). But there are few options to treat "madness;" most wizards seem to be left alone to cope with their conditions, unless, like Marvolo Gaunt $(H B P)$, they find themselves in trouble with the law. If the patient is dangerous or incapable of self-care, they are confined at the St. Mungo's Hospital closed ward until they recover on their own. Residents of the closed ward include Frank and Alice Longbottom, who were tortured into insanity by the Cruciatus curse; amnesic Gilderoy Lockhart, a victim of his own backfiring Obliviate charm and Broderick Bode, whose attempt to remove a prophecy from the Department of Mysteries left him mentally addled and believing that he was a teapot $(\operatorname{Oot} P)$.

While the patients are cared for physically at St. Mungo's, there are no apparent efforts to improve their mental state through potions, counter-spells or therapy. The capacity for recovery seems to depend on the initial degree of damage: the Longbottoms' condition was largely unchanged after 14 years; Lockhart had, in three years, recovered only a few skills like cursive writing; Bode, after several months, was making progress and would likely have recovered fully had the Death Eaters not murdered him. Even with the respect the young Albus Dumbledore had garnered in the scholarly community, his 
family apparently never considered seeking treatment for Ariana's trauma-induced magical outbursts; fearing commitment at St. Mungo's, they chose instead to keep her hidden, with tragic results. If Dumbledore was unaware of therapeutic options, it is likely they simply did not exist. St. Mungo's Healers would probably find the idea of Mugggle psychiatric treatments as bizarre and incomprehensible as the use of stitches for flesh wounds. In short, wizard diagnostic criteria for psychological disorders seem not much more sophisticated than Ron's oft-asked question, "Are you mental?"

But, if the typical wizard is unfamiliar with psychology, Rowling is not. First, she was herself diagnosed and treated for a mental illness (Amini, 2008; Runcie, 2007;

Treneman, 2000). Second, it is unlikely the series would have achieved such success if it did not resonate with readers on multiple levels, including the psychological. When the lens of abnormal psychology is focused on the series, some creations and characters seem to mirror well-characterized psychological disorders. I will consider four examples in depth: 1) major depressive disorder (personified by dementors), 2) senile dementia of Alzheimer's type (Frank and Alice Longbottom), 3) post-traumatic stress disorder (Mad-Eye Moody) and 4) Stockholm syndrome (Winky). With Rowling's reputation for meticulous research, it is not surprising she has accurately depicted recognizable examples of these disorders, according to official diagnostic criteria.

\section{Dementors illustrate major depressive disorder and its treatment}

Whenever Harry encounters dementors, he feels "that stealing sense of despair, of hopelessness, filling him, expanding inside him.” (Rowling, 2007, p. 257). Unlike hippogriffs, centaurs, werewolves and other magical creatures that have a long mythological tradition, dementors are Rowling's own creation. Shortly before $G o F$ was 
published, Rowling acknowledged that dementors were based on her own experience with major depressive disorder (Treneman, 2000); however, the similarity of the effects to depressive symptoms is apparent to clinical psychologists even without citing that admission (e.g. Murakami, 2006).

Rowling inspired by her own diagnosis. Dementors were introduced in Harry Potter and the Prisoner of Azkaban (PoA) as "among the foulest creatures to walk this earth" (Rowling, 1999b, p. 187). Their ultimate weapon is a "kiss" that sucks out the human soul, or psyche, the root base of the word "psychology." Dementors guarded the oppressive Azkaban prison and, over Dumbledore's objections, were assigned to patrol Hogwarts to protect it from escapee Sirius Black. Harry was overwhelmed and fainted during his first encounter with them on the Hogwarts Express. Later, dementors were shown to be dangerous allies of both Voldemort and corrupt ministry officials. Umbridge sent two dementors to attack Harry in Little Whinging at the beginning of OotP. In Harry Potter and the Deathly Hallows $(\mathrm{DH})$, the dementors were used to intimate detainees in the kangaroo court set up by the Muggleborn Registration Commission; they later occupied Hogsmeade village and fought for Voldemort in the Battle of Hogwarts.

Dementors cause both Muggles and wizards to experience darkness, despair and cold. According to Lupin:

They infest the darkest, filthiest places; they glory in decay and despair, they drain peace, hope and happiness out of the air around them. Even Muggles feel their presence, though they can't see them. Get too near a dementor and every good feeling, very happy memory will be sucked out 
of you.... You'll be left with nothing but the worst experiences of your life (Rowling, 1999b, p. 187).

Rowling's depiction of clinical depression in the dementors was deliberate:

It was entirely conscious. And entirely from my own experience. Depression is the most unpleasant thing I have ever experienced. It is that absence of being able to envisage that you will ever be cheerful again. The absence of hope. That very deadened feeling, which is so very different from feeling sad (Treneman, 2000).

Rowling would eventually acknowledge that she had been suicidal during this period, but was successfully treated with counseling (Associated Press, 2008). In a separate interview that same year (Amini, 2008), she reported that her specific treatment was cognitive behavioral therapy (CBT).

[Table 1 about here]

Dementor effects cover all DSM-IV criteria. According to the $D S M-I V$, to be diagnosed with a major depressive episode, a patient must meet at least five of nine criteria, with at least one of the symptoms being either 1) daily depressed mood or 2) diminished interest or pleasure in activities (American Psychiatric Association, 2000). All nine of the $D S M-I V$ symptoms can be accounted for in Rowling's descriptions of dementor effects, with the two essential symptoms the most frequently mentioned (Table 1). Azkaban prisoners provide examples of $D S M-I V$ criteria 3-6: weight loss, sleep disturbance, psychomotor retardation and lost of energy (Table 1); as Sirius Black explains, they stop eating and otherwise "lose the will to live" (Rowling, 2000, p. 529). Criteria 7-9 (guilt, loss of concentration, obsessive thoughts of death and suicide) are best 
exemplified by the specific terrors induced in Harry (Table 1). When dementors approach, Harry loses his ability to think for himself and is forced to relive past encounters with death. His early difficulties in learning to use the Patronus Charm to repel dementors were complicated by the guilt he felt; he was terrified and distracted by his dying parents' screams but at the same time wanted to hear their voices (Rowling, 1999b, p. 247). In his final encounter with dementors at the Battle of Hogwarts, Harry could not stop thinking of the death that surrounded him and came close to a type of suicide:

Fred was gone, and Hagrid was surely dying or already dead... How many more lay dead that he did not yet know about; he felt as though his soul had already half left his body...A hundred dementors were advancing, gliding toward him, sucking their way towards Harry's despair... his own wand trembled in his hand, and he almost welcomed the oncoming oblivion, the promise of nothing, of no feeling...(Rowling, 2007, pp. 648649).

Only the intervention of his friends saved him from surrendering his life.

Dementor deterrents parallel depression treatments. In Rowling's world, there are two ways of counteracting dementor attacks. The first, chocolate, is a type of first aid used by both Professor Lupin and Madam Pomfrey to help students recover from an encounter. Chocolate, however, cannot actually stop a dementor attack. For that, Lupin taught Harry the "highly advanced" Patronus Charm (PoA); Harry not only mastered it at a surprisingly young age but also taught it to his classmates in Dumbledore's Army $($ OotP $)$. Both of these remedies have homologues in Muggle approaches to treating depression. Chocolate is widely used as folk remedy, although empirical evidence 
suggests that any effectiveness is limited (Parker, Parker \& Brotchie, 2006). The Patronus Charm bears a number of similarities to $\mathrm{CBT}$, the treatment Rowling received and which she enthusiastically has promoted to others (Amini, 2008).

The magic of chocolate. Chocolate is the standard treatment for dementor attacks in the wizarding world. Lupin distributed it on the Hogwarts Express after the students' first encounter. When Harry ate it, he "felt warmth spread suddenly to the tips of his fingers and toes" (Rowling, 1999b, p. 86) as it counteracted the dementor-induced chill. Madam Pomfrey immediately suggested chocolate when they arrive at Hogwarts, and, when Harry assured her they had already eaten some, she was delighted that "we've finally got a Defense Against the Dark Arts teacher who knows his remedies" (Rowling, 1999b, p. 90). Lupin also supplied Harry with Chocolate Frogs and a bar of Honeyduke's finest during his Patronus Charm lessons, telling him "Eat the lot, or Madam Pomfrey will be after my blood" (Rowling, 1999b, p. 242). After their encounter with dementors at the Black Lake, Madame Pomfrey treated Ron, Harry and Hermione with a block of chocolate that "looked like a small boulder" (Rowling, 1999b, p. 388), forcing it into Harry's mouth when he resisted.

Muggles are equally appreciative of the "magical" properties of chocolate. The scientific name of the chocolate plant, Theobroma cacao, translates into "food of the gods." Chocolate is popularly believed to be a "feel-good" food and cravings for it are common (Parker, Parker \& Brotchie, 2006). Depressed women, in particular, report not only craving chocolate but also feeling relief from depression and anxiety when it is consumed (Parker \& Crawford, 2007). Interestingly, Parker \& Crawford (2007) reported that the more depressed patients were also more likely to comfort themselves with 
warming stimuli like hot baths, as if they were trying to combat the psychological "coldness" that dementors physically induce.

Chocolate contains the methylxanthine stimulants caffeine and theobromine (Rose, Koperski \& Golomb, 2010) as well as cannabinoid-like molecules resembling the active ingredients in marijuana (di Tomaso, Beltramo \& Plomelli, 1996), although levels are likely insufficient to cause measurable behavioral or mood effects at normal doses. Unfortunately, chocolate does not "cure" depression; regular chocolate eaters actually have higher depression scores than less frequent consumers (Rose et al., 2010). One possibility for this finding is that depressed Muggles "self-medicate" with chocolate even without pressure from Madam Pomfrey (Rose et al., 2010). Another explanation of the correlation of high chocolate consumption with depression is that chocolate has a overall deleterious effect on mood and that its apparent benefits are temporary or illusory (Rose et al., 2010).

After an extensive review of the scientific literature, Parker et al., (2006) concluded:

For most people, chocolate invokes anticipatory and consummatory pleasure and is therefore an indulgence. When taken in response to a dysphoric state... it may provide some transient "comforting" role but is more likely to prolong rather than abort the dysphoric state. It is not, as some would claim, an antidepressant (p. 157).

Even Harry found chocolate of little use once he had learned to master the Patronus Charm. After being force-fed so much in the hospital wing, he lost his appetite for chocolate treats from the Hogwarts Express trolley (Rowling, 1999b, p. 431). 


\section{The Patronus Charm resembles cognitive behavioral therapy. The Patronus}

Charm differs from chocolate in that it can repel dementors, rather than simply treat the symptoms of an encounter. According to Lupin:

The Patronus is a kind of positive force, a projection of the very things that the dementor feeds upon- hope, happiness, the desire to survive- but it cannot feel despair, as real humans can, so the dementors can't hurt it. (Rowling, 1999b, p. 237).

The Patronus Charm was considered advanced magic, not typically taught at Hogwarts except in the most advanced classes and was not mastered by all wizards. Early in training $(P o A)$, Harry managed to conjure only silver smoke or clouds; later he produced a fully corporeal Patronus in the shape of a stag, the Animagus representation of his father. Patronuses often take the form of an animal representing someone emotionally important to the wizard: Tonks' took the form of a werewolf after she fell in love with Lupin, while Snape's Silver Doe represented his unrequited love for Lily.

The incantation for the Patronus Charm, "Expecto Patronum" is effective only when the wizard is focusing on a happy memory or some other positive visualization. Thus, at the very moment the dementor is distracting and weakening its victim though forced recall of pain, the wizard is counteracting the effect with positive thoughts. This technique is very similar to the core principle of CBT, initially developed by Aaron T. Beck as a treatment for depression in the 1960's (Beck Institute, n.d.). Beck found that depressed patients tended to automatically formulate negative thoughts about themselves, the world and the future. CBT is a process through which patients would be taught to identify, evaluate and replace the dysfunctional thoughts with more positive ones. 
Rowling successfully underwent nine months of CBT during the worst of her depression and would later state, "It worked for me, so obviously I'm very pro- $[\mathrm{CBT}] \ldots$ and it gives you strategies for hereafter...I want to tell everyone that they must go and get help.” (Amini, 2008). Given Rowling's enthusiasm for CBT, it is not surprising that Harry not only mastered the Patronus Charm but also taught his Dumbledore's Army comrades to use it.

Recent studies confirm that depressed patients have difficulty summoning positive memories. Patients diagnosed with depression do not differ from controls in their ability to recall sad memories, but rate their happy memories as less vivid (WernerSeidler \& Moulds, 2011). Furthermore, positive memories are best able to relieve depression if they are recalled in a concrete, rather than abstract, manner (Werner-Seilder $\&$ Moulds, 2012). By OotP, Harry has learned to make his memories not just happy but also vivid; Ron's and Herminone's faces "burst clearly into his mind" (Rowling, 2003, p. 18) as he successfully performed the charm during the Little Whinging attack on himself and Dudley.

\section{[Table 2 about here]}

\section{Harry's Patronus-summoning memories mitigate depression. Though Harry}

objected to Madam Pomfrey's characterization of him as "delicate" in the face of dementor attacks, he was more vulnerable to their effects than many of his peers, just as children in the Muggle world who have experienced parental loss or mistreatment are more vulnerable to depression (Kaufman, 1991; Kaufman et al., 2004; Smith \& Palmieri, 2007). However, the visualizations Harry uses to summon his Patronus fall into two categories that correspond to factors known to reduce or moderate the chances of 
developing depression: past successes or escapes from adversity and social support. (Table 2).

Harry's victories prevent learned helplessness. In the 1970's Seligman and colleagues proposed the learned helplessness model of depression (Abramson, Seligman $\&$ Teasdale, 1978). Researchers had confirmed that both animals and humans who were exposed to inescapable adversity (such as shock or loud noise) tended to develop a helpless "depressed" state in which they would stop trying to escape the noxious stimulus and endure it passively. A perception of chronic defeat and the feeling of being trapped are both known risk factors for the development of major depression (Taylor, Gooding, Wood \& Tarrier, 2011). However, subjects that were previously given an opportunity to escape the stimulus (by, for instance, turning off the noise by pulling a lever) were less likely to learn helplessness when later exposed to inescapable adversity. Prior successes and escape from adversity escape therefore seem to confer a measure of "immunity" to depression (Abramson, Seligman \& Teasdale, 1978).

Fittingly, many of the memories Harry used to summon his Patronus take the form of successful escapes or other victories he had achieved (Table 2). This type of memory was particularly common early in his training, with five of the seven happening in $P o A$, and all by the end of OotP. Reminding a patient of past accomplishments is exactly what CBT would suggest for a depressed patient who was had fallen into the hopelessness mindset.

The importance of a social support network. Strong social support can reduce the likelihood of clinical depression in both children and adults (Kaufman, 1991; Peirce, Frone, Russell, Cooper \& Mudar, 2000). Mistreated children, even if they were 
genetically predisposed to develop depression, had reduced depressive symptoms if they had a strong social support network (Kaufman et al., 2004). "Supporter" was defined as a person children could depend on to either 1) talk to about personal matters 2) obtain advice 3) share good news with 4) have fun with and 5) buy them what they need (Kaufman, 1991). Harry had little, if any, such support while living with his Dursley relatives, but found them all, in abundance, after he enrolled in Hogwarts. Ron and Hermione were Harry's biggest source of support, meeting four of the five criteria directly, while Hagrid and Molly Weasley, stepped in to meet the fifth, taking him to buy needed supplies in Diagon Alley and providing him with birthday and Christmas gifts. Eventually, Harry would gain more support through a series of surrogate fathers: Dumbledore, Lupin, Sirius and Arthur Weasley.

During the last three books in the series, after Harry became adept at using the Patronus charm, he thought of Ron and Hermione on four different occasions when fighting dementors (Table 2). This emphasizes the importance of those friendships in warding off the dangers of the dementors and, ultimately, in securing Voldemort's defeat. The importance of emotional connections can also be seen in the tendency of a Patronus to assume a symbol of a loved one.

It is during his final $D H$ encounter with a platoon of dementors outside Hogwarts that the connection of the Patronus Charm with both CBT and social support becomes most obvious. Harry was despondent over the death of Fred and apparent loss of Hagrid in the battle, and, for the first time, he was unable to conjure his Patronus when needed. After Ron's and Hermione's Patronuses failed as well, Harry was at the point of giving up and allowing the dementors to overtake him. Just in time, some representatives from 
Harry's wider circle of friends, Luna Lovegood, Ernie McMillian and Seamus Finnegan, arrived with their own Patronuses and held off the dementors long enough for Harry to regroup. These allies, representing all the Houses of Hogwarts except Slytherin, demonstrate the broad base of Harry's social support network. Luna took on the unlikely role of cognitive behavioral therapist as she helped Harry restructure his negative thoughts.

"That's right," said Luna encouragingly, as if they were back in the Room of Requirement and this was simply spell practice for the D.A. "That's right, Harry ... come on, think of something happy."

“Something happy?" he said, his voice cracked.

"We're all still here, " she whispered. "We're still fighting. Come on now..."

There was a silver spark, then a wavering light and then, with the greatest effort it had ever cost him, the stag burst from the end of Harry's wand. (Rowling, 2007, p. 649).

Not only did Rowling create the dementors in response to her own experience with major depressive disorder, but in choosing the Patronus Charm as only effective weapon against them, she has given us a literary representation of CBT. While chocolate may provide some temporary and illusory relief to wizards suffering from post-dementor syndrome and Muggles suffering from clinical depression, the Patronus Charm and CBT provide a long-term means for banishing the despair. Interestingly, in $H B P$, Snape claims to favor a different means of fighting dementors in his Defense against the Dark Arts class, though readers are never told what that is. One possibility is that the talented 
Potions-master had some sort of concocted medicinal remedy in mind, perhaps the wizarding equivalent of an antidepressant drug.

It is also worth noting that, while CBT was originally developed to treat depression, it is now used in a variety of therapeutic settings, both in the treatment of other psychiatric disorders and in the management of everyday behavioral and emotional challenges. Similarly, the Patronus Charm eventually comes to have other uses in the series. The Order of the Phoenix uses it as a means of secure communication, dispatching it to speak a message in the sender's voice. Dumbledore used it to summon Hagrid when he found Viktor Krum stunned $(G o F)$, Kinglsey Shacklebolt warned the Weasley wedding party that the Ministry had fallen, Arthur Weasley assured Ron of his family's safety and Professor McGonagall conjured three Patronuses to call allies to the Battle of Hogwarts $(D H)$. Finally, Snape used his silent doe Patronus in the Forest of Dean to covertly lead Harry to the Sword of Gryffindor, an important symbol of courage and power $(D H)$.

Relevance for Readers. Depression is the most common of all mental illnesses; $6.9 \%$ of U.S. adults and $9.1 \%$ of adolescents have at least one depressive episode every year (NIMH, 2012a; 2102b). Rowling's willingness to speak publically about her illness and treatment is an intentional effort to de-stigmatize the condition and encourage readers to seek treatment (Amini, 2008). Natov praises the capacity of the series to help young readers understand the condition:

I remember fits of depression as a child, though without any name for that state of mind, it went unrecognized and was buried, along with the shame that all my unacknowledged feelings... Shame separates us, makes us feel 
less than, different from others... At times, [Rowling] handles it with the acceptance that comes from humor; at times, with a respect that accompanies our most difficult emotional trials. (Natov, 2001).

As the first generation of Harry Potter readers become young adults, at least some have gotten the message. In February 2015, a group of students at the University of Virginia sponsored a mental health awareness event called "The Patronus Project" that included panels where students spoke about their own experiences, mental health screenings by the university counseling center, yoga classes and benefit concerts (Kass, 2015). The event's slogan was "Everyone has Dementors."

Multiple clinical psychologists (Mulholland, 2006; Noctor, 2010; Robinson 2012) have Rowling's magical spells useful as a metaphor in therapy, especially with children. Even before Rowling spoke publically about her treatment with CBT in 2008, Rippetoe recognized the similarity between the Patronus Charm (along with the Riddikulus Charm that banishes Boggarts, Dark shape-shifting creatures that assume the form of phobias) and CBT:

The rudiments of the Riddikulus and Patronus Charms, first described in Prisoner of Azkaban, demonstrate clearly the necessity-- even in the wizarding world-- for changing thought processes to master powerful defenses against the Dark side.... How comforting to know that a bit of the wizarding world is available to us Muggles and that, in times of great Darkness, we, too, can learn from a good cognitive therapist to cast spells against the Darkness (Rippetoe, 2006). 
The early trauma of Harry's life may have made him more susceptible to dementors than his peers. By making her hero particularly vulnerable, Rowling helps to dispatch the myth that depression is a result of character weakness. Thanks to Harry's escape to Hogwarts, the social bonds he found there, and the knowledge of how to channel those forces via the Patronus Charm, Harry learned to defeat dementors, much as Rowling learned to manage her depression. Through Harry's, and Rowling's example, Muggles can learn that there is no shame in seeking treatment.

\section{The Longbottoms as Alzheimer's disease victims}

After Voldemort's downfall at the end of the first Wizarding War, Aurors Frank and Alice Longbottom were attacked by Death-Eaters Bellatrix, Rodolphus and Rabastan LeStrange and Barty Crouch, Jr. and tortured with the Cruciatus Curse for information about Voldemort's whereabouts. Though they survived the attack, they were left permanently damaged, unable to speak, care for themselves and with no memory of their infant son Neville. As is typical for mentally incapacitated witches and wizards, they were institutionalized in the closed ward of St. Mungo's, leaving Neville in the care of his grandmother Augusta. According to the DSM-IV (American Psychiatric Association, 2000, p. 157) dementia of Alzheimer's type is characterized by profound memory impairment occurring with other cognitive deficits such as those seen in the Longbottoms (e.g., loss of language and executive function). Though the DSM-IV does not list stages, the Alzheimer's Association describes seven different stages of the disease (Alzheimer's Association, 2012); the Longbottoms' lack of verbal ability puts them at the seventh, most severe stage. 
Rowling's inspiration. Like many advanced Alzheimer's patients, Alice Longbottom did not explicitly recognize Neville as her son, but did respond to him as a familiar person. This familiarity was shown by her habit of handing him Droobles bubble gum wrappers during his visits to the hospital. Though his grandmother advised Neville to throw them away, saying "She must have given you enough of them to paper your bedroom with by now" (Rowling, 2003, p. 315), Harry saw Neville instead tuck the paper into his pocket. Rowling acknowledges that the scene at St. Mungo's was inspired by a friend's experience:

I was told a very sad story by someone I know about their elderly mother who had Alzheimer's, and the elderly mother was in a closed ward. She was very severely demented and no longer recognized her son, but he went faithfully to visit her twice a week, and he used to take her sweets. That was the point of their connection, she recognized him as the sweetgiver. That was very poignant to me. So I embroidered the story. Neville gives his mother what she wants, and... she wants to give something back to him, but what she gives back to him is essentially worthless. But he still takes it as worth something because she's trying to give, so it does mean something, in emotional terms (Anelli \& Spartz, 2005).

Thus, while some Harry Potter fans may have hoped the Droobles wrappers would carry some significant message from the ex-Auror to aid her son in the fight against Voldemort, the truth turned out to be simpler, and perhaps more beautiful. The wrappers were a tenuous sign of familiarity, giving Neville his only meaningful emotional link to 
his brain-damaged mother. Sadly, the Longbottoms were never cured of their condition, just as there is no cure for Alzheimer's disease in the Muggle world.

Neville fits the profile of an Alzheimer's “orphan.” Some of Neville's vulnerabilities parallel those of the children of Alzheimer's patients. Alastor Moody remarked that the Longbottoms were "better dead than what happened to them" (Rowling, 2005, pp. 173-174). Many family members of Alzheimer's patient report feeling like their loved one has died once the patient can no longer recognize them. Davidson (2006) titled the memoir of caring for her Alzheimer's disease-afflicted husband A Curious Kind of Widow. Neville is in many ways as much an orphan of Voldemort as Harry was.

When Neville encountered his friends at St. Mungo's Hospital during his Christmas visit, he was embarrassed to have them know about his parents' condition and looked "thoroughly depressed" (Rowling, 2005, p. 312). As with Harry, the loss of his parents at a young age might be expected to predispose Neville to depression; unlike Harry, it not clear whether Neville ever manages the Patronus Charm. Sons of Alzheimer's patients are especially prone to depression when 1) they did not have a close relationship to the parent before the disease developed and 2) when they do not have strong community for support (Williamson \& Schulz, 1990). Because Neville was a baby when his parents were attacked, he never had a chance to form a real relationship with them. He also chose not to confide in his classmates about their condition, perhaps because he feared becoming even more of a social outcast. Both of these factors would have increased his likelihood for depression and could account for some of Neville's insecurities. 
Effects of being raised by a grandmother. Augusta raised Neville after his parents were incapacitated. Solomon and Marx (1995) found that, while children raised by grandparents are typically as physically healthy as children living with their parents, they tend to have lower levels of academic achievement. Neville, who "very rarely heard the he was good at anything" (Rowling, 2000, p. 221), had difficulties with his most of his Hogwarts classes. He did not qualify for N.E.W.T level transfiguration and especially struggled with potions. Smith and Palmieri (2007) report a variety of psychological issues among children raised by grandparents compared to the general population, including emotional troubles, attention deficits and difficulties with peers. The attention problems and peer difficulties were especially pronounced in boys being raised by grandmothers; Neville had a poor memory and was unpopular with classmates. Another study (Pruchno, 1999) found that Caucasian grandmothers reported higher levels of unhappiness, immaturity, introversion, dependency and lower self-esteem in the grandchildren they were raising, while Black grandmothers were more likely to report disobedience, antisocial and violent behaviors. With his academic challenges, forgetfulness, lack of confidence and social awkwardness, Neville in many ways fits the profile of a Caucasian child raised by grandparents, especially during the first four books of the series.

Neville's resilience. Like Harry, Neville managed to overcome the difficulties of his childhood. As early as Harry Potter and the Sorcerer's Stone (SS, Rowling, 1998), he started to acquire the same type of social connections and successes that assisted Harry, albeit to a lesser extent. He showed an early aptitude for herbology, even as he struggled with other subjects; his successes there helped to counterbalance his other difficulties. Harry, Ron and Hermione befriended him during their first year and urged him to stand 
up to Malfoy's bullying. Harry told him, "You're worth twelve of Malfoy. The Sorting Hat chose you for Gryffindor, didn't it?" (Rowling, 1998, p. 218). The high point of Neville's first year was earning the critical ten points that secure the House Cup for Gryffindor, which he does by finding the courage to stand up to his friends. In $\operatorname{Oot} P$, he strengthened both his knowledge and his social ties through Dumbledore's Army, where he proved himself an apt pupil, and assisted in the raid in the Department of Mysteries. In $H B P$, he was one of the few of Dumbledore's Army alumni to defend Hogwarts against the invading Death-eaters.

Sybil Trelawny's prophecy about Voldemort's defeat could have referred to either Harry or Neville.

The one with the power to vanquish the Dark Lord approaches... born to those who have trice defied him, born as the seventh month dies... and the Dark Lord will mark him has his equal, but he will have the power the Dark Lord knows not... and either must die at the hand of the other for neither can live while the other survives (Rowling, 2003, p. 841).

It was Voldemort's choice to attack baby Harry, rather than Neville, that made the world see Harry the "Chosen One," destined to defeat Voldemort. However, by the series end, Neville had emerged as the leader of the student rebellion in Hogwarts, and was ultimately chosen by the Chosen One to continue the mission of Horcrux destruction after Harry realized he must sacrifice himself. Neville's actions at the Battle of Hogwarts fulfilled the prophecy as much as Harry's did. Voldemort "marked him as an equal" when he placed the Sorting Hat on Neville's head to symbolically re-sort him into Slytherin. By defying Voldemort and refusing to live under his rule, Neville showed 
Gryffindor-typical courage and found "the power the Dark Lord knows not" when he pulled Gryffindor's sword from the hat. Neville assured Voldemort's mortality when he killed Nagini, the final Horcrux. Just as the crucial ten points in SS tipped the House Cup balance in favor of Gryffindor, Neville's destruction of the last Horcrux tipped the balance in favor of Harry. Thus, Neville played a small, but essential, role in Voldemort's defeat.

After the war, Neville further overcame his early disadvantages to achieve confidence and success as an adult. As shown in the $D H$ epilogue, he remained close to Harry and Ron's families and became a respected professor of herbology at Hogwarts. All in all, it was a remarkable transformation for the child who was best known in his first year for losing toads, melting cauldrons and falling off broomsticks. As with Harry, social support and learned success rather than helplessness were essential to Neville's recovery.

Relevance for Readers. While Harry's challenge of defeating an evil wizard is in the realm of pure fantasy, many Harry Potter readers have faced or will face the more common challenges that Neville faces. In the United States alone, 5.1 million people have Alzheimer's disease or some other form of dementia, with that figure expected to climb $40 \%$ over the next decade because of the aging population demographics (Alzheimer's Association, 2015). Around 3 million parents split their time between caring for minor children and caring for a parent with dementia. (Alzheimer's Association, 2015). Additionally, the AARP (2010) reports that 5.8 million children live in a grandparent's home and 2.5 million U.S. grandparents are the sole caregivers for their grandchildren. 
In many ways, Neville' weaknesses make him a more accessible role model to readers than is Harry. While Harry seems to become an expert flyer, star Quidditch player and defensive spell master with little effort, Neville works hard but must content himself with his own less prestigious skills in herbology and charms (Kalish \& Kalish, 2006). Friis (2013) states "Harry takes on the role of the typical fictional hero whereas Neville serves the role of the everyday hero who is one among all of the ordinary people. As a result, he becomes a character to relate to because he provides the readers with a glimpse of hope." (p. 15). Asher-Perrin (2013) calls Neville, "the truest of Gryffindors and a surprising balancing point of the entire Harry Potter narrative." By giving Neville a more common set of challenges, and showing him persevering to emerge as a true hero alongside Harry, Rowling provides a more realistic role model in the midst of her magical world. Neville becomes an example of how even ordinary people can make essential contributions to worthy causes.

\section{Mad-Eye Moody as caricature of post-traumatic stress disorder}

Rowling has never publically stated that the character of Alastor "Mad-Eye" Moody was inspired by anyone she knew with post-traumatic stress disorder (PTSD), but the resemblance is noticeable. A disabled veteran of the Persian Gulf War describes Moody as "a darned fine example of what happens to a good person... when the shooting stops. ... How J. K. Rowling gained her insight into the veteran's condition, I do not know, but she has fleshed out a great character to reflect this particular aspect of war and society." (Lewis, 2007). 
Moody's PTSD symptoms. The DSM-IV lists 17 possible criteria for PTSD; Moody ${ }^{1}$ displays at least eight, including the two essential ones (Table 3). Those are 1) past experience with events that involved or threatened death or serious injury and 2) a response to the event of intense fear, helplessness or horror (American Psychiatric Association, 2000). Moody was a veteran of the First Wizarding War and a member of the original Order of the Phoenix, meaning he had fought Voldemort on multiple occasions. He had survived repeated injuries, while 11 of his old comrades had been lost, some in quite gruesome ways. Moody had been considered a top Auror and had successfully captured many Dark Wizards, but like many combat veterans, he was "regaled in war, reviled in peace" (Lewis, 2007) and had difficulty adjusting to civilian life. Though her reporting is always suspect, Rita Skeeter claimed that Moody, "retired from the ministry when he could no longer tell the difference between a handshake and attempted murder" (Rowling, 2000, p. 203).

\section{[Table 3 about here]}

Two other PTSD criteria, intrusive memories of the event and irritability, are illustrated by his first and last name (Table 3). Moody displayed the fifth symptom, hypervigilance, in the $\operatorname{Oot} P$ visit to Privet Drive when, in the face of Tonks' disgust, he insisted on removing, cleaning and replacing his eyeball in the Dursley's kitchen, declaring, "I want three-hundred-and-sixty-degree visibility on the return journey" (Rowling, 2003 p. 51).

\footnotetext{
${ }^{1}$ Some of the described traits come not from the real Alastor Moody but from the period in $G o F$ when a disguised Barty Crouch Jr. was impersonating Moody. However, I will assume Crouch's behaviors were consistent with the real Moody's character, since Crouch successfully deceived even Moody's close friend Dumbledore for nearly an entire school year.
} 
Moody also showed an exaggerated startle reflex and over-reactivity to stimuli that resemble the original trauma, such as loud noises (Table 3). Moody had a long record of overreacting to supposed dangers, often jeopardizing the Statute of Secrecy in the process. Moody was introduced at the beginning of $G o F$, when he was suspected of setting off exploding dustbins in response to a false intruder alarm, attracting the notice of Muggle police and necessitating emergency intervention by Arthur Weasley. Amos Diggory, the Ministry employee who delivered the message, was obviously used to Moody's antics:

“Arthur, you know Mad-Eye, “ said Mr. Diggory’s head, rolling its eyes again. "Someone creeping into his yard in the dead of night? More likely there's a very shell-shocked cat wandering around someplace, covered in potato peelings" (Rowling, 2000, p. 159-160).

Rowling's choice of the term "shell-shocked" is itself interesting, since that term originated to describe a syndrome seen in World War I veterans, now known to be the result of combined brain injury and psychological trauma that produces symptoms overlapping with those of PTSD (Jones, Fear \& Wessely, 2007).

Finally, Moody was constantly afraid for his life, expecting a foreshortened future. In $\operatorname{Oot} P$, when leading the party to escort Harry from Privet Drive, Moody was overly anxious, utterly convinced an attack was imminent. He instructed his team "If one of us is killed... the others keep flying, don't stop, don't break ranks. If they take out all of us and you survive, Harry, the rear guard are standing by to take over; keep flying east and they'll join you" (Rowling, 2000, p. 35). At this point, Voldemort's return was not publicly acknowledged, and he had thus far shown no signs of attacking. Nymphadora 
Tonks, Moody's protégé, was visibly irritated at his excessive caution, while Kingsley Shacklebolt, another experienced Auror and Order member, calmly assured Harry that, "No one's going to die," (Rowling, 2000, p. 35). The general consensus seemed to be that Moody was being irrational on this occasion.

No cure but more war. In keeping with the relative lack of magical psychiatric cures, Rowling provides no clear treatment for Moody's condition; he is typically left to his own devices unless he creates a disturbance. Ironically, the best "cure" for Moody was the start of the Second Wizarding War. This also parallels aspects the Muggle experience of PTSD: some affected military personnel are eager to return to combat situations where their hypervigilence and extreme reactivity are not considered a abnormal liability, but a trait beneficial for survival (Bracha \& Maser, 2008: van ZuylenWood, 2007). After Dumbledore's death in $H B P$, the Order turned to Moody to be their new leader. By then, Harry regarded him not as crazy, but "so tough, so brave, the consummate survivor" (Rowling, 2007, p. 78). The same level of caution in OotP that had an exasperated Tonks shouting, “Are you mad, Mad-Eye?!” (Rowling, 2000, p. 57) was considered perfectly reasonable two years later in $\mathrm{DH}$, when the Order liberates Harry a second time. It is not Moody's attitude or behavior that has changed, but the circumstances; the war had begun and Voldemort had become an unquestionable threat. "Constant vigilance!" was now a sensible choice.

Sadly, even Moody's elaborate "Seven Potters" plan was insufficient to avoid casualties, and Moody himself died in that rescue effort. Harry put to rest any notion of Moody being "mad" when he chose to rescue Moody's magical eye from Umbridge's door in the Ministry of Magic, even though that action ultimately gave away their 
mission cover. Harry showed admiration for Moody's strength, wisdom and courage when he buried the eye under the "oldest, most gnarled and resilient-looking tree he could find" (Rowling, 2007, p. 285), carving a cross on the trunk in the fallen soldier's memory.

Relevance for Readers. As with Alzheimer's disease, PTSD is a condition that many Harry Potter readers can expect to encounter, with a lifetime risk of $7-8 \%$ for the general U.S. population and 14-16\% for veterans (Gates et al., 2012). Harry's admiration of Moody despite his obvious PTSD tendencies has the capacity to reduce stigmatization of PTSD patients. Rowling's own empathy for traumatized war veterans became even more obvious in her most recent writing effort, the Cormoran Strike mystery series. Not only is her protagonist a wounded Gulf War veteran, Rowling is publishing the series under the pen name "Robert Gailbraith" who claimed, in the original "about the author" description to be a veteran of the British military now working in civilian security. Interestingly, Detective Strike, who, like Moody, lost a leg in combat, shows some PTSD symptoms; notably, flashbacks to the explosion in which he was injured and others died. Whether Strike will be diagnosed with full-blown PTSD, and whether Rowling will demonstrate the same knowledge of symptoms and treatment as she does for depression remains to be seen.

The true PTSD victim: Harry or Moody? To date, the scholarly literature has largely ignored the connection between PTSD and Mad-Eye Moody. Interestingly, the character academics are most likely to reference as having PTSD symptoms is Harry himself. In one sense, this is understandable; between the murder of his parents has a baby, the abuse he suffered from the Durseleys and the multiple attempts by Voldemort 
to kill him, Harry has certainly faced his share of trauma; as Lupin tells him, "There are true horrors in your life, horrors your classmates can scarcely imagine." (Rowling, 199b, p. 237). Both Murakami (2006) and Mulholland (2006) characterize Harry's dementorinduced flashbacks of his parents' murder as reliving the trauma, a well-known PTSD symptom that Moody does not show. In a more extreme example, Sanna (2014) argues that the entire Harry Potter series can be interpreted as a metaphor for the stress-induced traumatic repression and recovery of childhood sexual abuse memories, with the pain Voldemort triggers in Harry's scar representing the fragmented memory of Voldemort's mind-penetrating attack on Harry as a baby.

However, Harry is a less convincing example of a PTSD patient than Moody. Murakami and Mulholland both focus only the history of trauma and the flashbacks; a PTSD diagnosis requires a minimum of eight symptoms. They do not acknowledge Rowling's own statements about dementors the connection to depression, a very different disorder, although, in their defense, their work was published before most of the interviews in which Rowling spoke of her diagnosis. Sanna (2014) attributes more PTSD symptoms to Harry, but selectively interprets the book series to do so. For example, Sanna describes Harry as frequently "irascible and agitated," referencing his behavior in OotP as an example; Harry is actually quite even-tempered most of the time, especially compared to Ron, Fred and George Weasley. Sanna also cites Harry's occasional need to isolate himself from his friends (again, $\operatorname{Oot} P$ is the main example) as indicative of the PTSD symptom of detachment from others, ignoring the fact that Harry usually relishes the companionship of his Hogwarts peers. Finally, the PTSD-like traits Murakami, Mulholland and Sanna describe occur only intermittently in Harry, whereas they are the 
core of Moody's character. The DSM specifies that for a PTSD diagnosis, symptoms must endure for at least a month, with significant damage to the ability to function in school, work or relationships: a description that fits Moody, but not Harry.

Indeed, Harry is seen by others (e.g. Provenzano \& Heyman, 2006) as a model of resiliency. This is probably why the Harry Potter series has proved useful in helping children cope with terror and (Katz, 2003; Strimmel, 2004) and why therapists (e.g. Merkell \& Merkell, 2008; Noctor, 2006) find Harry Potter-themed interventions helpful for treating traumatized children, including those with PTSD.

\section{Winky as Stockholm syndrome victim}

Stockholm syndrome is a condition in which hostages or prisoners form an emotional attachment to their captors, even to the point of resisting rescue. The term was coined after a 1973 bank robbery in Stockholm, Sweden, during which, after six days of being held prisoner in a vault and threatened with guns and strangulation, the hostages identified with their captors and viewed the police as the enemy. They remained loyal to their captors after their rescue, contributed money towards their defense fund and refused to testify against them. Unlike depression, Alzheimer's disease and PTSD, Stockholm syndrome is not listed in the $D S M-I V$ and there is no universally recognized set of criteria for how to diagnose it (Namnyak et al., 2008). Nonetheless, it is a syndrome known widely in the popular media and evoked to help explain the behavior of well-known kidnap victims such as Patty Hearst (Namnyak et al, 2008). The Stockholm syndrome model has also been expanded beyond the hostage-captor relationship to explain why battered women may choose to stay with their abusers (Follingstad, Neckerman \& Vormbrock, 1988; Martinez, 2001) and the childlike dependency that existed between 
some African-American slaves and their masters in the American South (HuddlestonMattai \& Mattai, 1993). Like PTSD, Stockholm syndrome is hypothesized to have an evolutionary basis, with the emotional attachment characterized as a form of appeasement that may have increased the odds of survival against a stronger and inescapable enemy (Cantor \& Price, 2007). Thus, even without inclusion in the DSM-IV, there is at least some general agreement on the effects of Stockholm syndrome and the conditions that can lead to its development (Namnyak et al, 2008).

In the wizarding world, house-elves are an enslaved class. Some, like Dobby in $\operatorname{CoS}$, openly dislike their masters and resist following orders to the best of their ability. Others, like Winky, $(G o F)$ are slavishly devoted to the wizards they serve and view freedom as not just undesirable, but disgraceful.

Factors that promote Stockholm syndrome. Stockholm syndrome is most likely to develop when 1) hostages cannot escape and depend on the captor for their lives 2) hostages are isolated with their captors and kept away from contact with others and 3) the captor threatens to kill the captives or is thought to have the ability to do so and 4) the captor shows periodic kindness or mercy to the hostages (Martinez, 2001; Namnyak et al, 2008). The first three of these conditions are met in the wizarding world institution of house-elf slavery. House-elves are magically bound to their family for multiple generations, presumably through some sort of long-term spell that prevents escape and is only broken if the master gives the elf clothing. House-elves typically cannot leave their owner's house without explicit orders or permission, so contact with others is limited. They are also denied their full magical potential by being forbidden to use wands. Although it is not clear how common this practice is, wizards can clearly kill elves in 
their household with impunity, as evidenced by the mounted heads lining the hallway of 12 Grimmauld Place $(\operatorname{Oot} P)$. In $C o S$, Dobby reports getting regular death threats from the Malfoys. Even Professor Slughorn $(H B P)$ had no qualms about risking house-elf lives to check his wine bottles for poison. Given these oppressive circumstances, it would not be surprising to see house-elves who are at least occasionally well-treated develop Stockholm syndrome.

Why Winky was vulnerable. As initially described by Ochberg in the late 1970's, Stockholm syndrome includes one or more of the following: 1) positive feelings for the captor by the hostage both during and after captivity 2) negative feelings towards rescuers and 3) the perception of positive feelings reciprocated by the captor for the hostage (Follingstad, et al, 1988; Huddlestone-Mattai \& Mattai, 1993; Namnyak et al., 2007). Winky clearly illustrates the first and second traits: she was devastated at being dismissed, continues to long for and defend her master, Barty Crouch Sr., and, like the rest of the Hogwarts house-elves, is insulted by Hermione's insistence that would be better off free. When, in GoF, Hermione reminds her of Mr. Crouch's cruelty in dismissing her, Winky responses, "You is not insulting my master, miss! You is not insulting Mr. Crouch! Mr. Crouch is a good wizard, miss!” (Rowling, 2000, p. 380). As for the third, reciprocal affection is clearly not there, since Mr. Crouch regarded Winky "as though she were something filthy and rotten that was contaminating his over-shined shoes" (Rowling, 2000, p. 138). However, the captor does not need to actually be affectionate, only be perceived as such by the captive. This may take the form of an occasional small act of kindness or less cruel than normal treatment amid a background of abuse (Martinez, 2001). As Huddleston-Mattai and Mattai (1993) explain, "Because 
the master or captor did not implement the worst expectations of the slaves or captives.... a sense of relief is felt and the master or captor is now revered as a good person" (pp. 347-348).

Despite the harshness of Mr. Crouch, Winky seems to have a history of reasonably good treatment, at least by house-elf standards (Seymour, 2012). Even at the worst of her distress, she did not physically self-punish the way Dobby does, suggesting she had not been forced to do so or otherwise bodily abused in the Crouch household. Winky was entrusted with concealing and caring for Barty Jr., her master's "most important secret," which gave her a sense of both responsibility and being needed. After being freed and going to work at Hogwarts, she laments, "My poor Mr. Crouch, what is he doing without Winky? He is needing me, he is needing my help!" (Rowling, 2000, p. 381). Winky even had a measure of influence over her owner and was able to convince him to give Barty Jr. occasional treats, like attending the Quidditch World Cup. This is a major contrast to Dobby, who justifiably felt he was "treated like vermin" in the Malfoy home (Rowling, 1999a) and consequently would be expected to show no sign of Stockholm syndrome. Given that Winky and Dobby knew each other, Winky could probably discern that she was the better treated of the two, which in turn led her to perceive Mr. Crouch as a kind or even generous master. Thus, Winky's situation in the Crouch household met all three traits that would be expected to predispose her to Stockholm syndrome.

Slavery and Stockholm syndrome. When Stockholm syndrome is applied to slavery, the slaves must not only become convinced that their masters are good, they must also accept their own position as part of the natural order. 
The other side [of Stockholm syndrome] is what is referred to as the ascribed definition of self, that is, the definition that is forced upon the slave or captive by the master or captor. Although there is an inherent perception in the intent of the master or captor that the slave or captive must be brainwashed into believing that those responsible for their demise are good, it is equally important to cause the slave or captive to accept their inherent inferiority as part of their cultural antecedents, (HuddlestonMattai and Mattai, 1993, p. 348).

Winky had clearly accepted her inferior caste, given her rebuke of Dobby after the latter had the audacity to expect wages as a free elf. She said, "No, no, no, I says to Dobby, I says, go find yourself a nice family and settle down, Dobby. He is getting up to all sorts of high jinks, sir, what is unbecoming to a house-elf”' (Rowling, 2000, p. 98). After her own dismissal, Winky wept in the Hogwarts kitchen:

I is looking after the Crouches all my life, and my mother is doing it before me, and my grandmother is doing it before her... oh, what is they saying if they knew Winky was freed? Oh, the shame, the shame! (Rowling, 2000, p. 381).

Like many survivors of trauma (Follingstad, et al., 1988), Winky turned to alcohol to cope with the stress. The butterbeer addiction she exhibited in GoF and OotP was one from which, according to a post-publication interview with Rowling, Winky would never fully recover (Wizarding World Press, 2004). However, Rowling also confirmed in a later chat with fans that Winky "dried out after a bit," and, by $D H$, was physically and mentally healthy enough to participate in the house-elf attack on the Death Eaters at the 
Battle of Hogwarts (Bloomsbury Publishing, 2007). Although we do not know what factors contributed to her partial recovery in the latter two books, it was likely a combination of magical enslavement, her cultural legacy and relatively humane treatment in the Crouch home that caused Winky to develop a Stockholm syndrome-like state, not unlike some slaves in the Muggle world (Huddleston-Mattai and Mattai, 1993.) In contrast, the much more brutal treatment Dobby received made him both despise his masters and yearn for his freedom and a savior in the form of Harry Potter.

Relevance for Readers. The likelihood that a Harry Potter reader would wind up in a hostage or kidnapping situation in which Stockholm syndrome might develop is happily remote. However, understanding the reasons behind Winky's seemingly illogical wish to remain enslaved is still important. To date, no scholarly articles have considered the question of Stockholm syndrome in house-elves. When Winky and other house-elves turn up in literary analysis of the Harry Potter series, they are usually considered a model for the oppression of women (Kellner, 2010), the exploitation of marginalized racial groups (Green, 2009; Seymour, 2012) or both (MacNeil, 2002). Kellner calls Winky “a female's female; even for an effeminate race she is easily scared...the submissive female elf, one who is convinced of the righteousness of the chauvinist social order" (Kellner, 2010, p. 376), while Seymour says, “Winky's story, of an elf with no autonomy outside of the institution of slavery, is illustrative of the stock narrative which wizards tell themselves to justify their position in the social hierarchy." (Seymour, 2012, p. 32). MacNeil draws the racial parallel even more closely, characterizing the house-elves' demeanor as "reminiscent of either wide eyed 'Uncle Toms' or giggling 'Oriental' houseboys...behaviour expected of all 'subaltern subjects,' be they black, yellow or 
brown, by 'white mythology's' race power." (MacNeil, 2002, p. 553). Given the links that have been forged between Stockholm syndrome and the seemingly misplaced loyalty of both battered women and slaves, it is not unreasonable to expect Winky to show the symptoms.

More than anything, Winky demonstrates the difficult moral dilemmas surrounding any solution for the effects of institutionalized discrimination. Green (2009) states, "The young reader gaining experience alongside Harry slowly begins to understand, as Harry does to some extent, that these terrible injustices inflict an emotional toll on human and magical creature alike." Before Winky's introduction in $G o F$, it could be assumed that only the villains of the series, such as the Malfoys, would enslave other magical creatures and that all elves, like Dobby, would prefer to be free. Winky's introduction heralds "a quite radical turn by showing that elf slavery is not only considered normal in the wizarding world, but is actually considered an obligation by some wizards who view freeing house-elf slaves as cruel and unjust" (Seymour, 2012, p. 32). Even virtuous characters like the Weasleys cannot envision a world without houseelves as slaves; neither can most house-elves. Hermione's naïve efforts to free them are unwelcome and ultimately misguided, as she attempts to impose human values on them instead of trying to understand the elves' culture and mental state. (Nuttal, 2013).

An understanding of Winky can help readers understand how oppression, whether a short-term hostage situation or a centuries-old cultural institution like slavery, leaves psychological damage that cannot be undone by simply setting the prisoner free. As Dumbledore said, "We wizards have mistreated and abused our fellows for too long, and are now reaping our reward" (Rowling, 2003, p. 834). Even the wise Headmaster has no 
easy solution to the problem of house-elf enslavement, but the ethical dilemma provides growth opportunities for the readers' moral reasoning abilities. Seymour notes, "By beginning the series with simple right and wrong and slowly progressing to the later stages, to the point where readers can engage with moral ambiguities, the narratives assist in the development of morality at the same time that they mimic it." (Seymour, 2012, p. 37). The gradual unfolding of the plight of the house-elves may partially explain why Harry Potter readers show less stigmatization of marginalized groups (Vezzali et al., 2014).

\section{Potential applications}

The Harry Potter series can clearly be used as an educational tool to explain psychological theories and practices (Murakami, 2006; Mulholland, 2006, Rippetoe, 2006). The sound behavioral science underlying the Harry Potter series has led to its use as a therapeutic aid for children, particularly those suffering from trauma or grief (Merkell \& Merkell, 2008; Noctor, 2006). More recent research has shown that exposing children to Harry Potter scenes in which bigotry is depicted as wrong is associated with reduced reports of prejudice, including prejudice against groups that are not explicitly depicted in the series (Vezzali et al., 2014). Given that Harry, the Longbottoms, Moody and Winky are all depicted as sympathetic characters, it is possible that reading Harry Potter could also be a means of reducing the stigma of seeking help through therapy and increasing empathy for Muggles with mental illness and their families.

[Figure 1 about here]

Recent pilot data collected by Mary Baldwin College students in an interdisciplinary honors colloquium on human morality provide some preliminary 
support for that hypothesis. The students surveyed 138 of their classmates about their exposure to and fondness for Harry Potter books and movies. They also administered several scales that measured both general and specific empathic tendencies. Specifically, students were asked how comfortable they would be taking a class with a professor being treated for a variety of mental and physical ailments. They also took a test measuring their own tolerance of PTSD patients (e.g. stating their agreement with sentences like "I would be comfortable with a person being treated for PTSD living in my building.") and perceived societal stigmatization (e.g. "I think most people would be reluctant to hire someone being treated for PTSD”).

[Figure 2 about here]

In the sample, 25 students reported never reading Harry Potter, 45 had read between one and four books and 68 had read all seven. Students who had read the full series scored higher on several empathy and tolerance measures (Figure 1). While there were no measurable differences between empathic concern (compassionate feelings for others in distress) or perceived societal stigmatization of PTSD, the series readers were significantly higher in generalized perspective-taking (the tendency to see situations from another's point of view) and personal tolerance of PTSD (Fig. 1). The complete series readers also indicated much more comfort with not only with PTSD patients, but also with people being treated for other conditions as well (Fig. 2).

This correlation does not prove that exposure to Harry Potter increases empathy and comfort levels; it entirely possible that more compassionate people are attracted to Rowling's novels and their strong anti-bigotry message. Clearly, the findings must be replicated in a larger and more representative sample before any definitive conclusions 
could be drawn. But the results are consistent with other work (Vezzali et al., 2014) that found reduced prejudice against marginalized groups in students who read and engaged with the Harry Potter novels, as well as a larger body of work (e.g. Kidd \& Castano, 2013; Johnson, 2012; Mar \& Oatley, 2009) suggesting that active engagement with literary fiction promotes prosocial behavior. The unmatched capacity of Rowling's books to so actively engage readers of all ages, combined with her sympathetic and ultimately optimistic portrayal of the mentally ill may give her books the power cast a spell of acceptance over the wider Muggle population.

\section{Conclusion}

Rowling has no formal training in psychology and it is unlikely that she perused the peer-reviewed literature as part of her research in writing the Harry Potter series. Nonetheless, she has provided fictionalized personifications of at least four recognizable clinical syndromes. Her depiction of major depressive disorder through the imagery of dementors is perhaps the most deliberate and complete. Her choices to make her protagonist particularly vulnerable to dementor effects and to have him master the Patronus Charm to escape them were undoubtedly inspired by her own diagnosis and successful treatment. While Rowling's experiences with depression and CBT undoubtedly enhanced the vividness of the dementor descriptions and elevated the importance of the Patronus Charm in the series, there is also evidence she examined the disorder in a more objective fashion. It is unlikely that she would have coincidentally included all nine of the $D S M-I V$ criteria in the effects of dementors without some research into professional diagnostic guidelines. 
Similarly, her characterization of both Mad-Eye Moody and Winky suggest Rowling is well informed about both PTSD and Stockholm syndrome, two wellcharacterized reactions to trauma or entrapment. Whether through her own research or the observations she made of acquaintances, she managed to use the Longbottom family to illustrate the effects of Alzheimer's-like dementia not only on the patient, but also on family members. The behavioral traits of her characters turn out to be well-supported by empirical research. Examples include the relative ineffectiveness of chocolate as depression management tool, the ability of past successes and established social support to mitigate depression, and the academic and social challenges faced by children raised by grandparents. Whether this is the result of Rowling's keen insight into the human condition or actual research into the topics is unknown, but it seems unlikely that a writer whose attention to detail led her to plant a "false lily" in the Dursley's garden would not have consulted some psychology resources before writing scenes inspired by depression and dementia. Basic knowledge of psychology, including familiarity with the symptoms of a number of psychiatric disorders, seems to form part of the "internal logic" of Rowling's magical world, even if the wizards themselves barely acknowledge the psychological sciences.

In a documentary film (Runcie, 2007), Rowling stated that bigotry was the trait she despised above all others. Her books carry an explicit anti-prejudice message, with groups like Muggleborns and house-elves serving as proxies for historically marginalized people groups of the non-magical world; this message seems to be effective in reducing prejudice in readers (Vezzali et al., 2014). The recognizable psychological disorders depicted in Harry Potter provide a less obvious, but equally powerful call to reduce the 
stigma of mental illness and extend understanding and acceptance to mental health patients and their loved ones. 


\section{References}

Abramson, L. Y., Seligman, M. E. P., \& Teasdale, J. D. (1978). Learned helplessness in humans: Critique and reformulation. Journal of Abnormal Psychology 87(1), 4874.

AARP (2010). More Grandparents Raising Grandkids. Retrieved May 15, 2015 from http://www.aarp.org/relationships/grandparenting/info-122010/more_grandparents_raising_grandchildren.html

alastor. (n.d.). Online Etymology Dictionary. Retrieved May 07, 2012, from

Dictionary.com website: http://dictionary.reference.com/browse/alastor.

Alzheimer's Association (2012). Seven stages of Alzheimer's. Retrieved May 08, 2012, from http://www.alz.org/alheimers disease stages_of alzheimers.asp.

Alzheimer's Association (2015). 2015 Alzheimer's Disease Facts and Figures. Retrieved May 15, 2015, from https://www.alz.org/facts/downloads/facts_figures_2015.pdf.

American Psychiatric Association. (2000). Diagnostic and Statistical Manual of Mental Disorders, $\left(4^{\text {th }}\right.$ ed., text revision) Washington, DC: American Psychiatric Association.

Amini, A. (2008). The Minister of Magic: Adeel Amini delves into JK Rowling's chamber of secrets. The Edinburgh Student. Retrieved May 07, 2012, from http://gallery.the-leaky-cauldron.org/default/fullpic/207262.

Anelli, M., \& Spartz, E. (2005). The Leaky Cauldron and Mugglenet Interview Joanne Kathleen Rowling: Part III. Retrieved May 07, 2012, from http://www.accioquote.org/articles/2005/0705-tlc Mugglenet-anelli-3.htm. 
Asher-Perrin, E. (2013) Neville Longbottom is the Most Important Person in Harry Potter-And Here's Why. Retrieved May 15, 2015 from http://www.tor.com/2013/11/19/neville-longbottom-is-the-most-importantperson-in-harry-potter/.

Associated Press (2008, March 28). Report: Author Rowling considered suicide. USA Today, Retrieved May 07, 2012, from http://www.usatoday.com/life/people/200803-23-rowling-report_N.htm.

Beck Institute (n.d.) The History of Cognitive Behavioral Therapy. Retrieved May 07, 2012, from http://www.beckinstitute.org/history-of-cbt/.

Binnendyk, L., \& Schonert-Reichl, K. A. (2002). Harry Potter and moral development in pre-adolescent children. Journal of Moral Education, 31(2), 195-201.

Bloomsbury Publishing (2007) J.K. Rowling and the Live Chat. Retrieved May 09, 2012 from http://www.accio-quote.org/articles/2007/0730-bloomsbury-chat.html/.

Bracha, H. S., \& Maser, J. D. (2008). Anxiety and posttraumatic stress disorder in the context of human brain evolution: A role for theory in DSM V? Clinical Psychology: Science and Practice, 15(1), 91-97.

Brown, S., \& Patterson, A. (2010). Selling stories: Harry Potter and the marketing plot. Psychology \& Marketing, 27(6), 541-556.

Cantor, C., \& Price, J. (2007). Traumatic entrapment, appeasement and complex posttraumatic stress disorder: evolutionary perspectives of hostage reactions, domestic abuse and the Stockholm syndrome. Australasian Psychiatry, 41(5), 377-384. 
Chase, M. W., Reveal, J. L., \& Fay, M. F. (2009). A subfamilial classification for the expanded asparagalean families Amaryllidaceae, Asparagaceae and Xanthorrhoeaceae. Botanical Journal of the Linnean Society, 161(2), 132-136.

Conn, J. J. (2002). What can clinical teachers learn from Harry Potter and the Philosopher's Stone? Medical Education, 36(12), 1176-1181.

Davidson, A. (2006). A Curious Kind of Widow: Loving a man with advanced Alzheimer's. McKinleyville, CA: Daniel and Daniel.

di Tomaso, E., Beltramo, M., \& Plomelli, D. (1996). Brain cannabinoids in chocolate. Nature 382, 677-678.

Follingstad, D. R., Neckerman, A. P. and Vormbrock, J. (1988). Reactions to victimization and coping strategies of the battered woman: The ties that bind. Clinical Psychology Review 8, 373-390.

Frank, A. J., \& McBee, M. T. (2003). The use of Harry Potter and the Sorcerer's Stone to discuss identity development with gifted adolescents. Prufrock Journal, 15(1), $33-38$.

Friis, C. (2013). Abandoned Children in Literature: The Orphans in JK Rowling's Harry Potter and the Philosopher's Stone. Retrieved May 15, 2015 from http://lup.lub.lu.se/student-papers/record/4067356.

Gates, M. A., Holowka, D. W., Vasterling, J. J., Keane, T. M., Marx, B. P., \& Rosen, R. C. (2012). Posttraumatic stress disorder in veterans and military personnel: Epidemiology, screening, and case recognition. Psychological services, 9(4), 361382. 
Gibson, D. M. (2007). Empathizing with Harry Potter: The use of popular literature in counselor education. The Journal of Humanistic Counseling, Education and Development, 46(2), 197-210.

Granger, J. (2008a). How Harry Cast his Spell: The Meaning and Mania Behind J.K. Rowling's Bestselling Books. Carol Stream, IL: Tyndale Momentum.

Granger, J. (2008b). The Deathly Hallows Lectures: The Hogwarts Professor Explains the Final Harry Potter Adventure. Allentown, PA: Zossima Press.

Granger, J. (2012). St. Andrews: the conference at Scotland's oldest University. Retrieved 17 January 2015 from http://www.hogwartsprofessor.com/st-andrewsthe-conference-at-scotlands-oldest-university/.

Green, A. M. (2009). Revealing discrimination: social hierarchy and the exclusion/enslavement of the other in the Harry Potter novels. The Looking Glass: New Perspectives on Children's Literature, 13(3).

Harry Potter Conference (n.d.) Web page of the annual Harry Potter conference at Chestnut Hill College. Retrieved 17 January 2015 from http://www.harrypotterconference.com.

Hippard, V. L. (2007) Who invited Harry? A depth psychological analysis of the Harry Potter phenomenon. Dissertation Abstracts International Section A: Humanities and Social Sciences, Vol 68(4-A), 2007, 1469.

Hsu, C. T., Jacobs, A. M., Altmann, U., \& Conrad, M. (2015). The magical activation of left amygdala when reading Harry Potter: an FMRI study on how descriptions of supra-natural events entertain and enchant. PloS one, 10(2), e0118179. 
Huddleston-Mattai, B. A., \& Mattai, P. R., (1993). The Sambo mentality and the Stockholm syndrome revisited: Another dimension to an examination of the plight of the African-American. Journal of Black Studies 23(3), p. 344-357.

Johnson, D. R. (2012). Transportation into a story increases empathy, prosocial behavior, and perceptual bias toward fearful expressions. Personality and Individual Differences, 52(2), 150-155.

Jones, E., Fear, N., \& Wessely, S. (2007). Shell shock and mild traumatic brain injury: a historical review. American Journal of Psychiatry, 164(11), 1641-1645.

Kalish, C. \& Kalish, E. (2006). Hogwarts Academy: Common sense and school magic. In Mulholland, N. (Ed.) The Psychology of Harry Potter: An Unauthorized Examination of the Boy Who Lived, 59-73. Dallas, TX: BenBella Books.

Kass, D. (2015) Harry Potter-themed program at UVA takes aim at mental health. The Daily Progress. Retrieved 18 May 2015 from http://m.dailyprogress.com/news/local/uva/harry-potter-themed-program-at-uvatakes-aim-at-mental/article_abb9073a-b7d9-11e4-a211cf7951658506.html?mode $=$ jqm.

Katz, M. (2003). Prisoners of Azkaban: Understanding intergenerational transmission of trauma due to war and state terror (with help from Harry Potter). Journal for the Psychoanalysis of Culture and Society, 8(2), 200-207.

Kaufman, J., (1991). Depressive disorders in maltreated children. Journal of the American Academy of Child and Adolescent Psychiatry 30(2), 257-265. 
Kaufman, J., et al. (2004). Social supports and serotonin transporter gene moderate depression in maltreated children. Proceedings of the National Academy of Science 101(49), 17316-17321.

Kellner, R. T. (2010). JK Rowling's ambivalence towards feminism: House elves -women in disguise- in the "Harry Potter" books. The Midwest Quarterly, 51(4), 367-385.

Kern, E. M. (2003). The wisdom of Harry Potter: what our favorite hero teaches us about moral choices. Amherst, NY: Prometheus Books.

Kidd, D. C., \& Castano, E. (2013). Reading literary fiction improves theory of mind. Science, 342(6156), 377-380.

Lewis, S. T. (2007) A soldier's heart in a mad eye: Harry Potter and PTSD. Retrieved May 08, 2012, from http://www.veteranstoday.com/2007/07/20/a-soldier-s-heartin-a-mad-eye/.

MacNeil, W. P. (2002). "Kidlit" as "Law-and-Lit": Harry Potter and the scales of justice. Law \& Literature, 14(3), 545-564.

Mar, R. A. and Oatley, K. (2009). The function of fiction is the abstraction and simulation of social experience. Perspectives on Psychological Science, 3(3), 173192.

Martinez, J. (2001). Hostages in the home: Domestic violence as seen through its parallel, the Stockholm syndrome. Minnesota Center Against Violence and Abuse. Retrieved May 09, 2012 from http://www.mincava.umn.edu/documents/clergybook/clergybook.html. 
Merkell, K.A. \& Merkell, M.A. (2008). The children who lived: using Harry Potter and other fictional characters to help grieving children and adolescents. London, UK: Routledge.

Mills, A. (2006). Harry Potter and the terrors of the toilet. Children's Literature in Education, 37(1), 1-13.

Moses, P. A. (2014). Literature and its mirroring affect on psyche: the case of Harry Potter. Dissertation Abstracts International: Section B: The Sciences and Engineering, Vol 75(2-B(E)).

Mulholland, N. (2006). Using psychological treatment with Harry. In Mulholland, N. (Ed.) The Psychology of Harry Potter: An Unauthorized Examination of the Boy Who Lived, 265-282. Dallas, TX: BenBella Books, Inc.

Murakami, J. L. (2006). Mental illness in the world of wizardry. In Mulholland, N. (Ed.), The Psychology of Harry Potter: An Unauthorized Examination of the Boy Who Lived, 175-188. Dallas, TX: BenBella Books, Inc.

Namnyak, M., et al. (2008). Stockholm syndrome: Psychiatric diagnosis or urban myth? Acta. Psychiatr. Scand. 117, 4-11.

Natov, R. (2001). Harry Potter and the Extraordinariness of the Ordinary. The Lion and the Unicorn, 25(2), 310-327.

Nelissen, R., \& Zeelenberg, M. (2009). When guilt evokes self-punishment: evidence for the existence of a Dobby Effect. Emotion, 9(1), 118-122.

Noctor, C. (2006). Putting Harry Potter on the couch. Clinical Child Psychology and Psychiatry, 11(4), 579-589. 
National Institute of Mental Health. (2012a). Major depression among adolescents. Retrieved May 18, 2015 from http://www.nimh.nih.gov/health/statistics/prevalence/major-depression-amongadolescents.shtml.

National Institute of Mental Health. (2012b). Major depression among adults. Retrieved May 18, 2015 from http://www.nimh.nih.gov/health/statistics/prevalence/majordepression-among-adults.shtml.

Noel-Smith, K. (2001). Harry Potter's Oedipal issues. Psychoanalytic studies, 3(2), 199207.

Nuttall, A. (2013). Wand Privilege: Perceptions of superiority and inferiority in wizarding society. In Ciolfi, L \& O'Brien, G. (Eds.) Magic is Might 2012: Proceedings of the International Conference. 74-83.

Parker, G., \& Crawford, J. (2007). Chocolate craving when depressed: a personality marker. British Journal of Psychiatry 191, 351-352.

Parker, G., Parker, I., \& Brotchie, H. (2006). Mood state effects of chocolate. Journal of Affective Disorders, 92(2), 149-159.

Peirce, R. S., Frone, M. R., Russell, M., Cooper, M. L., \& Mudar, P. (2000). A longitudinal model of social contact, social support, depression and alcohol use. Health Psychology 19(1), 28-38.

Provenzano, D., \& Heyman, R. (2006). Harry Potter and the resilience to adversity. In Mulholland, N. (Ed.) The Psychology of Harry Potter: An Unauthorized Examination of the Boy Who Lived, 105-119. Dallas. TX: BenBella Books, Inc. 
Prucho, R. A. (1999) Raising grandchildren: The experience of White and Black grandmothers. Gerontologist 39, 209-221.

Rippetoe, P.A. (2006). Defense Against the Real Dark Arts. In N. Mulholland (Ed.) The Psychology of Harry Potter: An Unauthorized Examination of the Boy Who Lived. (pp. 283-298). Dallas, TX: Benbella Books, Inc.

Robinson, J. C. (2012). Bibliotherapy with children. In Neimeyer, R. (Ed.) Techniques of grief therapy: Creative practices for counseling the bereaved, 306-311. New York: Routledge.

Rowling, J.K. (1998). Harry Potter and the Sorcerer's Stone. New York, NY: Scholastic Press.

Rowling, J.K. (1999a). Harry Potter and the Chamber of Secrets. New York, NY: Scholastic Press.

Rowling, J.K. (1999b). Harry Potter and the Prisoner of Azkaban. New York, NY: Scholastic Press.

Rowling, J.K. (2000). Harry Potter and the Goblet of Fire. New York, NY: Scholastic Press.

Rowling, J.K. (2003). Harry Potter and the Order of the Phoenix. New York, NY: Scholastic Press.

Rowling, J.K. (2005). Harry Potter and the Half-Blood Prince. New York, NY: Scholastic Press.

Rowling, J.K. (2007). Harry Potter and the Deathly Hallows. New York, NY: Scholastic Press. 
Rose, N., Koperski, S., \& Golomb, B. A. (2010). Mood food: chocolate and depressive symptoms in a cross sectional analysis. Archives of Internal Medicine, 170(8), 699-703.

Rosegrant, J. (2009). The deathly hallows: Harry Potter and adolescent development. Journal of the American Psychoanalytic Association, 57(6), 1401-1423.

Runcie, J. (Producer \& Director). (2007). JK Rowling... A Year in the Life [Motion picture]. United Kingdom: Independent Television.

Sanna, A. (2014). 'I can touch him now': Harry Potter as a Gothic narrative of trauma and homoerotic sexual abuse. Literary Refractions: a Journal of Literature, Cultural and Literary Translations. 9(1). Retrieved May 15, 2015 from http://hrcak.srce.hr/index.php?show=clanak\&id_clanak jezik=196271.

Seden, J. (2002). Parenting and the Harry Potter stories: a social care perspective. Children \& Society, 16(5), 295-305.

Seymour, J. (2012). Harry Potter and the house-elf rebellion. Write4Children, 2, 28-38. Simpson, A. (1998). Face to face with J.K. Rowling: Casting a spell over young minds. The Herald. Retrieved 17 January 2015 from http://www.accioquote.org/articles/1998/1298-herald-simpson.html.

Smith, G. C., \& Palmieri, P. A. (2007). Risk of psychological difficulties among children raised by custodial grandparents. Psychiatric Services 58(10), 1303-1310.

Solomon, J. C., \& Marx, J. (1995). “To Grandmother's house we go": Health and school adjustment of children raised solely by grandparents. Gerontologist 35(3), 386394. 
Stine-Morrow, E. A. (2007). The Dumbledore hypothesis of cognitive aging. Current Directions in Psychological Science, 16(6), 295-299.

Strimel, C. B. (2004). The politics of terror: rereading Harry Potter. Children's Literature in Education, 35(1), 35-52.

Taylor, P. J., Gooding, P., Wood, A. M., \& Tarrier, N. (2011). The role of defeat and entrapment in depression, anxiety, and suicide. Psychological Bulletin, 137(3), 391.

Treneman, A. (2000). J.K. Rowling, The Interview. The Times (UK) Retrieved May 07, 2012, from http://www.accio-quote.org/articles/2000/0600-times-treneman.html.

van Zuylen-Wood, S. (2011). Life after war: Perspectives on PTSD from Rhode Island Veterans. Retrieved May 08, 2012, from http://campusprogress.org/articles/life_after_war_perspectives_on_ptsd_from_rho de_island_veterans/.

Vezzali, L., Stathi, S., Giovannini, D., Capozza, D., \& Trifiletti, E. (2014). The greatest magic of Harry Potter: Reducing prejudice. Journal of Applied Social Psychology, 45(2), 105-121.

Welsh, C. (2007). Harry Potter and the underage drinkers: Can we use this to talk to teens about alcohol? Journal of Child \& Adolescent Substance Abuse, 16(4), 119-126.

Werner-Seilder, A. \& Moulds. M. L. (2011). Autobiographical memory characteristics in depression vulnerability: Formerly depressed individuals recall less vivid positive memories. Cognition \& Emotion 25(6), 1087-1103.

Werner-Seidler, A., \& Moulds, M. L. (2012). Mood repair and processing mode in depression. Emotion, 12(3), 470-478. 
Whited, L. (2008). 1492, 1942, 1992: The theme of race in the Harry Potter series. The Looking Glass: New Perspectives on Children's Literature, 10(1).

Whited, L. A., \& Grimes, M. K. (2002). What would Harry do? JK Rowling and Lawrence Kohlberg's theories of moral development. In Whited (Ed.) The Ivory Tower and Harry Potter: Perspectives on a Literary Phenomenon, 182-208. University of Missouri Press.

Williamson, G. M., \& Schulz, R. (1990). Relationship orientation, quality of prior relationship and distress among caregivers of Alzheimer's patients, Psychology and Aging 3(4), 502-509.

Winters, S. F. (2011). Bubble-wrapped children and Safe Books for Boys: The politics of parenting in Harry Potter. Children's Literature, 39(1), 213-233.

Wizarding World Press (2004) J. K. Rowling gives revealing answers in World Book Day chat. Retrieved May 09, 2012, from http://www.beyondhogwarts.com/story.20040304.html. 
Table 1 Dementor effects that parallel symptoms of major depression.

\begin{tabular}{|c|c|}
\hline Criteria from $D S M-I V-T R$ (p. 356) & Description of dementor effect \\
\hline $\begin{array}{l}\text { (1) Depressed mood, frequent feeling of } \\
\text { sadness }\end{array}$ & $\begin{array}{l}\text { (1) Ginny sobs and Ron feels "like I'd } \\
\text { never feel cheerful again." PoA, pp. 85-86. } \\
\text { (2) "He felt that stealing sense of despair, } \\
\text { of hopelessness, filling him." } D H, \text { p. } 257 \text {. } \\
\text { (3) People left "with nothing but the worst } \\
\text { experiences of their lives." PoA, p. } 187 .\end{array}$ \\
\hline (2) Loss of pleasure, interest & $\begin{array}{l}\text { (1) Dementors "drain peace, hope and } \\
\text { happiness from the air around them" } P O A \text {, } \\
\text { p. } 187 \text {. } \\
\text { (2) Azkaban prisoners are "incapable of a } \\
\text { single cheerful thought." } P O A, \text { p. } 188\end{array}$ \\
\hline (3) Weight loss & $\begin{array}{l}\text { Azkaban prisoners frequently stop eating. } \\
G o F, \text { p. } 529 \text {. }\end{array}$ \\
\hline (4) Sleep disturbances & $\begin{array}{l}\text { Azkaban prisoners "shrieked in their } \\
\text { sleep." GoF, p. } 529\end{array}$ \\
\hline $\begin{array}{l}\text { (5) Psychomotor retardation (slowing down } \\
\text { physically or mentally) }\end{array}$ & $\begin{array}{l}\text { (1) Barty Crouch Jr. "went quiet after a } \\
\text { few days" in Askaban GoF, p. } 529 \\
\text { (2)"Dementors are supposed to drain a } \\
\text { wizard of his powers is he is left with them } \\
\text { too long." POA, p. } 188\end{array}$ \\
\hline (6) Fatigue, loss of energy & $\begin{array}{l}\text { (1)“They don't need walls or water to keep } \\
\text { the prisoners in, not when they're trapped } \\
\text { inside their own heads." PoA, p. } 188 \text {. } \\
\text { (2) "[Harry] felt the last of his strength } \\
\text { leave him" PoA, p. } 385 \text {. }\end{array}$ \\
\hline (7) Feelings of worthlessness, guilt & $\begin{array}{l}\text { Under dementor influence, Harry feels guilt } \\
\text { at his desire to hear his parents' dying } \\
\text { voices } P O A \text { p. } 247 .\end{array}$ \\
\hline (8) Inability to think, concentrate & $\begin{array}{l}\text { (1) “With a huge effort, [Harry] fought to } \\
\text { remember- Sirius was innocent." PoA p. } \\
383 \text {. } \\
\text { (2) "Harry didn't understand. He couldn't } \\
\text { think anymore." PoA p. } 385 \\
\text { (3) “The dementor bore down on him, } \\
\text { panic fogging his brain." OotP, p. } 18 .\end{array}$ \\
\hline (9) Thoughts of death, suicide & $\begin{array}{l}\text { (1) Dementors make Harry relive his } \\
\text { parents' death. PoA } \\
\text { (2) At Little Whinging attack, Voldemort } \\
\text { taunts, "Bow to death, Harry. It might even } \\
\text { be painless." OotP, p. } 18 \text {. } \\
\text { (3) "[Harry] almost welcomed the } \\
\text { oncoming oblivion, the promise of nothing, } \\
\text { no feeling." DH p. } 649 \text {. }\end{array}$ \\
\hline
\end{tabular}


Table 2. Classifications of Harry's Patronus-summoning memories and visualizations

\begin{tabular}{|c|c|c|}
\hline Type & Visualization & Occasion \\
\hline \multirow[t]{7}{*}{ Success/Adversity Escape } & $\begin{array}{l}\text { First time riding a } \\
\text { broomstick. }\end{array}$ & $\begin{array}{l}\text { First lesson with Lupin, } \\
\text { PoA, Ch. } 12 .\end{array}$ \\
\hline & $\begin{array}{l}\text { Gryffindor winning house } \\
\text { championship. }\end{array}$ & $\begin{array}{l}\text { First lesson with Lupin, } \\
\text { PoA, Ch. } 12 \text {. }\end{array}$ \\
\hline & $\begin{array}{l}\text { Learning he would be } \\
\text { leaving Dursleys for } \\
\text { Hogwarts. }\end{array}$ & $\begin{array}{l}\text { First lesson with Lupin, } \\
\text { PoA, Ch. } 12 .\end{array}$ \\
\hline & $\begin{array}{l}\text { Prospect of leaving Dursleys } \\
\text { to live with Sirius. }\end{array}$ & $\begin{array}{l}\text { Dementor attack PoA. Ch. } \\
20 \text {. }\end{array}$ \\
\hline & $\begin{array}{l}\text { Realizing he had } \\
\text { successfully conjured Stag } \\
\text { Patronus. }\end{array}$ & $\begin{array}{l}\text { Dementor attack, } P o A \text {, } \\
\text { (time-turner version) Ch. } 21 .\end{array}$ \\
\hline & $\begin{array}{l}\text { Escaping hedge maze in } \\
\text { third Triwizard task. }\end{array}$ & $\begin{array}{l}\text { Repelling dementor } \\
\text { (actually a boggart) in maze. } \\
\text { GoF, Ch. } 31 .\end{array}$ \\
\hline & Umbridge being sacked. & $\begin{array}{l}\text { O.W.L. Exam, OotP, Ch. } \\
\text { 31. }\end{array}$ \\
\hline \multirow[t]{5}{*}{ Social support } & $\begin{array}{l}\text { Celebrating with Ron and } \\
\text { Hermione. }\end{array}$ & $\begin{array}{l}\text { Repelling dementor } \\
\text { (actually a boggart) in hedge } \\
\text { maze. GoF, Ch. } 31 \text {. }\end{array}$ \\
\hline & Ron and Hermione. & $\begin{array}{l}\text { Dementor attack in Little } \\
\text { Whinging, OotP, Ch. } 1\end{array}$ \\
\hline & Ron and Hermione. & $\begin{array}{l}\text { Resisting dementors in } \\
\text { Ministry of Magic, } D H \text {, Ch. } \\
13 \text {. }\end{array}$ \\
\hline & Ron and Hermione. & $\begin{array}{l}\text { Escape from dementors in } \\
\text { Hogsmeade } D H, \text { Ch. } 28 \text {. }\end{array}$ \\
\hline & $\begin{array}{l}\text { Harry's despair initially } \\
\text { prevents him from casting } \\
\text { Patronus; Three friends } \\
\text { assist. Luna reminds him } \\
\text { "We're all still here. We're } \\
\text { all still fighting" (DH, p. } \\
\text { 649). Harry recovers and } \\
\text { casts his own Patronus. }\end{array}$ & $\begin{array}{l}\text { Dementor attack at Battle of } \\
\text { Hogwarts, } D H, \text { Ch. } 32 \text {. }\end{array}$ \\
\hline
\end{tabular}


Table 3. Traits of Alastor Moody that parallel symptoms of post-traumatic stress disorder.

\begin{tabular}{|c|c|}
\hline Criteria from $D S M-I V-T R$ (pp. 467-8) & Trait or description \\
\hline $\begin{array}{l}\text { (1) History of trauma, injury, or risk of } \\
\text { death }\end{array}$ & $\begin{array}{l}\text { Long-time auror, war veteran, many scars, } \\
\text { injuries. Missing eye, leg and part of nose. }\end{array}$ \\
\hline $\begin{array}{l}\text { (2) Experienced fear, helplessness or horror } \\
\text { during traumatic event }\end{array}$ & $\begin{array}{l}\text { Shows Harry picture of original Order of } \\
\text { the Phoenix. "Benjy Fenwick, he copped it } \\
\text { too, we only ever found bits of him" GoF } \\
\text { p. } 174 \text {. }\end{array}$ \\
\hline (3) Intrusive recollections of event & $\begin{array}{l}\text { "Alastor" means "avenger," literally "one } \\
\text { who does not forget." (alastor, n.d.) }\end{array}$ \\
\hline (4) Irritability, outbursts of anger & $\begin{array}{l}\text { "Moody" means irritable, prone to bursts of } \\
\text { temper. Mad-Eye frequently shows this } \\
\text { personality trait. }\end{array}$ \\
\hline (5) Hypervigilance & $\begin{array}{l}\text { (1) Motto is "Constant vigilance!" } \\
\text { (2) Relies on magical eye sees beyond } \\
\text { typical visual range. }\end{array}$ \\
\hline (6) Exaggerated startle response & $\begin{array}{l}\text { (1) "Moody's been getting in trouble for } \\
\text { years, I reckon. Attacks first and asks } \\
\text { questions later." Ron, GoF, p. } 220 \text {. } \\
\text { (2) "He was extremely twitchy, jumping } \\
\text { every time someone spoke to him." GoF, p. } \\
720 \text {. }\end{array}$ \\
\hline $\begin{array}{l}\text { (7) Distress, reactivity to cues that } \\
\text { resemble event }\end{array}$ & $\begin{array}{l}\text { (1)“I'll bet he leapt out of bed and started } \\
\text { jinxing everything he could reach through } \\
\text { the window" Amos Diggory, GoF, p. } 160 \text {. } \\
\text { (2)“Did you hear him telling Seamus what } \\
\text { he did to that witch who shouted 'Boo' } \\
\text { behind him on April Fool's Day?" Ron, } \\
\text { GoF, p. } 233 \text {. }\end{array}$ \\
\hline (8) Expects foreshortened future & $\begin{array}{l}\text { (1) Feared poisoning, drank only from own } \\
\text { flask. } \\
\text { (2) Worried excessively about being killed } \\
\text { transporting Harry from Dursley's in OotP, } \\
\text { well before Voldemort's public return. }\end{array}$ \\
\hline
\end{tabular}




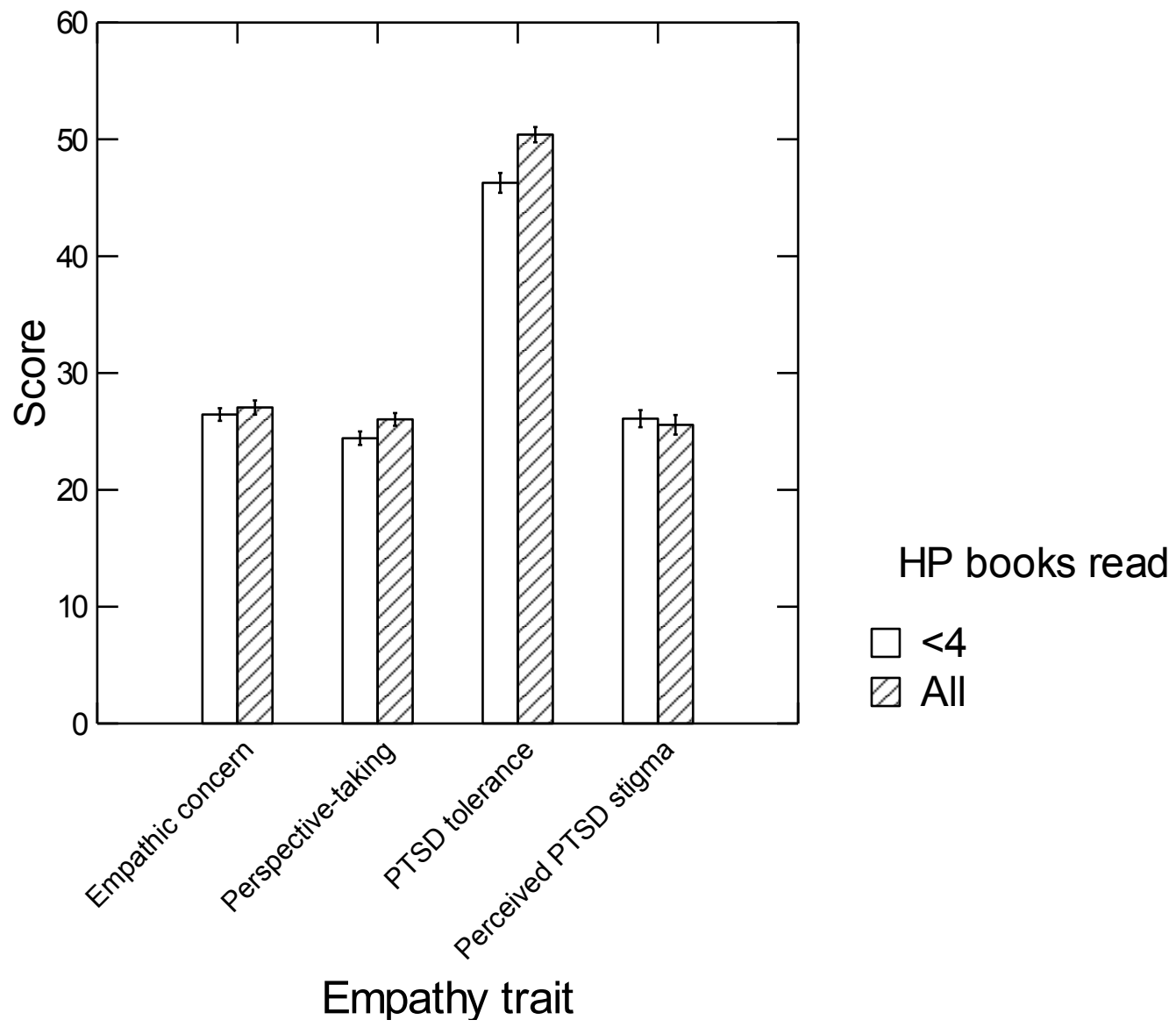

Figure 1. Differences in empathy and tolerance between students that had read the full Harry Potter series and those that had read four books or fewer. While complete Harry Potter series readers $(\mathrm{N}=68)$ did not differ from lesser readers $(\mathrm{N}=70)$ on empathic concern or perceived societal PTSD tolerance, they were significantly higher in perspective-taking and personal PTSD tolerance $(p<0.05)$. 


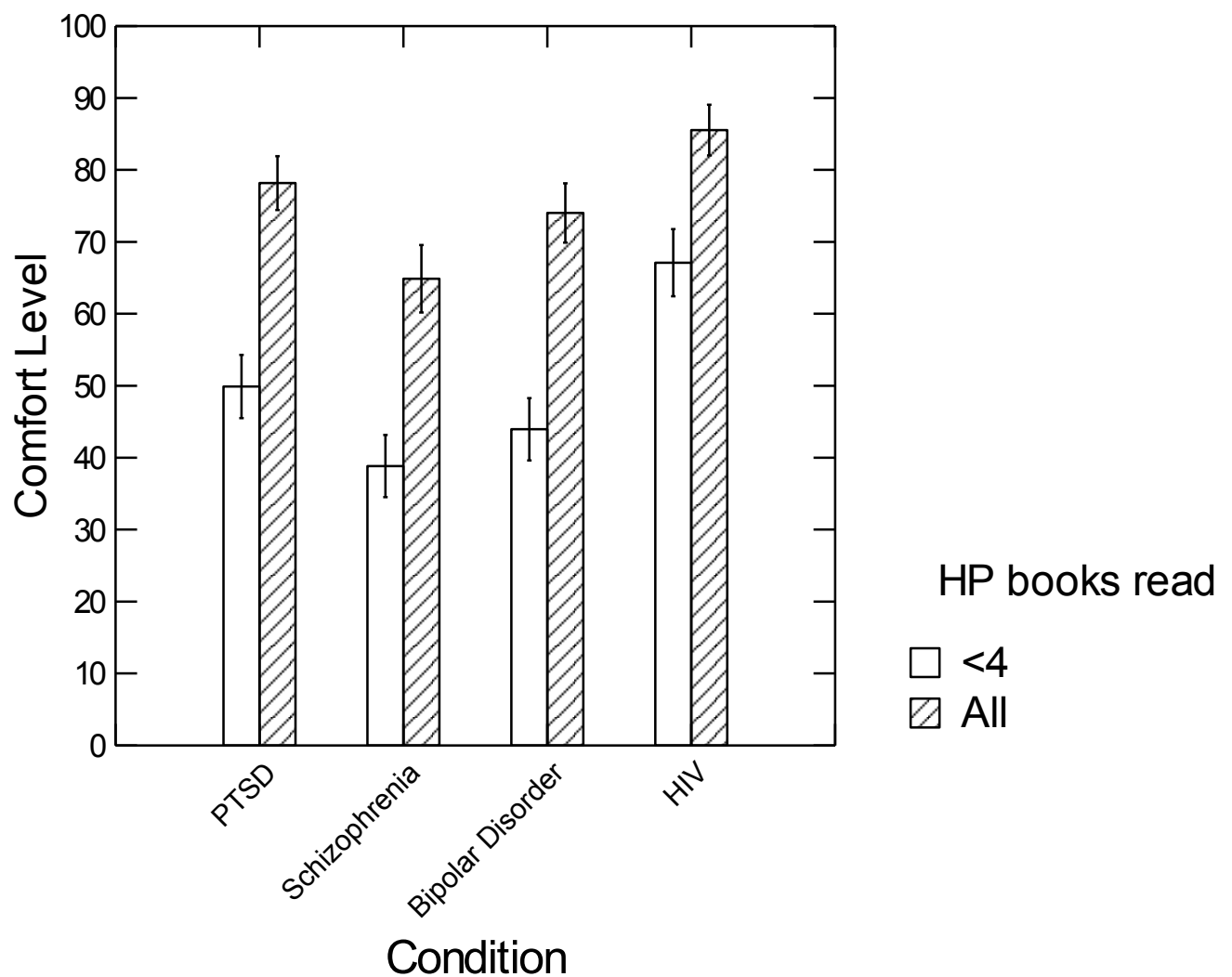

Figure 2. Differences in comfort levels between students that had read the full Harry Potter series and those that had read four books or fewer. Complete Harry Potter series readers $(\mathrm{N}=68)$ reported higher comfort levels than lesser readers $(\mathrm{N}=70)$ when asked how they would feel knowing their professor was being treated for PTSD, bipolar disorder, schizophrenia or HIV $(p<0.05)$. 